\title{
PENGEMBANGAN KLASTER AGROINDUSTRI DI DESA GONDANGAN KECAMATAN JOGONALAN KLATEN
}

\author{
Ida Susi $D^{1}$, Didik $I^{2}$, Asih Marini $W^{3}$ \\ ${ }^{1,2,3}$ Departemen Administrasi Bisnis, FISIP, UPN "Veteran” Yogyakarta, \\ Jl. Babarsari No. 2 Tambak Bayan Yogyakarta 55238 \\ email : idasusidewanti@yahoo.com
}

\begin{abstract}
ABSTRAK
UMKM makanan ringan yang ada di Desa Gondangan memiliki potensi untuk dikembangkan. Desa Gondangan berpotensi untuk dijadikan Desa kawasan Agroindustri, walaupun masih banyak yang perlu diperbaiki dan dipersiapkan.

Penelitian ini bertujuan untuk mengetahui sikap masyarakat tentang pengembangan UMKM di desa Gondangan menjadi kawasan kluster Agroindustri serta bagaimana partisipasi masyarakat dalam pengembangan UMKM di desa Gondangan untuk menjadi kawasan Agroindustri. Responden dalam penelitian ini adalah para pemimpin \& tokoh masyarakat setempat, warga masyarakat, pengusaha rumah tangga di wilayah Gondangan.

Penelitian ini merupakan penelitian deskriptif dengan pendekatan kualitatif. Data penelitian ini merupakan data primer dan data sekunder yang terdiri dari data kualitatif dan kuantitatif. Data primer diperoleh dengan dengan wawancara dan focus group discussion.

Hasil penelitian menunjukkan bahwa sikap masyarakat, pengusaha makanan ringan dan pemerintah setempat mendukung pengembangan kawasan Gondangan sebagai kawasan Agroindustri. Ditinjau dari aspek partisipasi pemerintah menunjukkan partisipasi dan dukungan yang tinggi dengan memfasilitasi berbagai kegiatan untuk mewujudkan kawasan Agroindustri, sedangkan pengusaha makanan ringan sebagai pelaku utama pengembangan kawasan Agroindustri tidak menunjukkan tingkat partisipasi yang tinggi.
\end{abstract}

Kata kunci : klaster, kawasan agroindustri, sikap masyarakat, partisipasi masyarakat.

\begin{abstract}
SMEs snacks in Gondangan village has the potential to be developed. The village has the potential to be Gondangan Agro-industry region, although it is still much that needs to be repaired and prepared.

This study aims to determine the attitude of the public about the development of SMEs in rural areas Gondangan into Agro-industry clusters and how community participation in the development of SMEs in rural areas Gondangan to be Agroindustri. Respondents in this study were the leaders and local community leaders, citizens, snack home industry in the region.

This study is a descriptive study with a qualitative approach. The data of this study is primary data and secondary data consists of qualitative and quantitative data. Primary data were obtained with the interview and focus group discussion.

The results showed that the attitude of the public, snack ho,e industri actor and local governments support the development of the region as an area of Agro-Industry cluster. In terms of participation, the government showed a high participation and support by facilitating a variety of activities to realize the region of Agro-Industry cluster, while the snacks businessman as the main actor of Agro-industry development of the area did not show a high level of participation.
\end{abstract}

Keywords: cluster, regional agro-industry, community attitudes, community participation. 


\section{PENDAHULUAN}

Pemerintah Kabupaten Klaten mempunyai program unggulan yaitu Kabupaten Agropolitan yang mempunyai tujuan untuk membangkitkan usaha mikro, kecil dan menengah (UMKM). Arah pengembangan kawasan agropolitan adalah menciptakan kawasan yang sejahtera dengan tumpuan hidup dari 5 Agro yaitu Agroproduksi, Agroindustri, Agrobisnis, Agroteknologi dan Agrowisata. Agroindustri merupakan sub sistem pencipta nilai tambah dari sebuah komoditas primer hasil pertanian. Melalui agroindustri ini maka sebuah komoditas pertanian diderivasi terus sampai sehilir-hilirnya untuk menghasilkan produk dengan nilai tambah yang lebih tinggi. Agroindustri atau pengolahan produk merupakan salah satu pendukung untuk terciptanya kawasan agropolitan. Sasaran akhir dari pengembangan agroindustri adalah meningkatnya produktivitas, daya saing produk agroindustri, nilai tambah produk pertanian, dan pendapatan masyarakat di perdesaan.

Penduduk Desa Gondangan sebagian besar mempunyai mata pencaharian di bidang produksi makanan ringan. Usaha yang dilakukan oleh kelompok masyarakat ini merupakan usaha perseorangan yang sudah berjalan puluhan tahun dan turun temurun. Sampai saat ini, usaha kecil makanan ringan menjadi usaha tetap masyarakat untuk menopang kehidupan keluarga, sehingga dapat meningkatkan pendapatan warga. Desa Gondangan dikenal sebagai Sentra Industri Kecil Mandiri dengan model pengelolaan usaha yang terwadahi dalam koperasi simpan pinjam untuk membantu para anggota dalam permodalan dan peningkatan produksi.

Wilayah Desa Gondangan sangat potensial untuk pertanian sehingga banyak produk pertanian dijumpai di daerah tersebut seperti jagung, kedelai, kacang, dan umbi-umbian. Warga desa Gondangan memanfaatkan hasil pertanian dengan mengolahnya menjadi cemilan atau jajanan pasar dan makanan ringan. Pengusaha kecil makanan ringan ini banyak yang bergabung dengan membentuk kelompok-kelompok seperti kelompok "Ngudi Mulyo", kelompok "Guna Darma", dan kelompok "Sumber Urip" dengan total jumlah anggota (industri rumah tangga) sebanyak 101 anggota.

UMKM makanan ringan yang ada di Desa Gondangan memiliki potensi untuk dikembangkan. Hal ini dikarenakan Sejak dulu camilan atau snack menjadi alternatif makanan bagi masyarakat di segala jenjang usia, mulai dari manisan, dodol, bakpia hingga beragam jenis keripik nikmat disantap setiap saat. Bisnis camilan atau makanan ringan mempunyai prospek yang cerah sepanjang waktu selama dibarengi dengan inovasi baru, baik dalam hal cita rasa, penampilan, pencitraan (image), serta trik-trik pemasaran yang selalu segar dan kreatif. Oleh karena itu perlu adanya suatu cara agar dapat mengembangkan UMKM yang ada di Desa Gondangan sehingga menjadi UMKM yang berhasil serta menjadi sentra industry makanan ringan di Kabupaten Klaten.

\section{METODE PENELITIAN}

Penelitian ini menggunakan metode penelitian dan pengembangan atau research and development yaitu metode penelitian yang digunakan untuk menghasilkan produk tertentu, dan menguji keefektifan produk tertentu. Lokasi penelitian ditentukan secara purposive atau dipilih secara sengaja. Karakteristik wilayah penelitian yang dipilih sesuai dengan tujuan penelitian, yaitu suatu desa yang memiliki UKM dan menghasilkan produk olahan hasil pertanian. Lokasi penelitian ditentukan di desa Gondangan sebagai lingkungan yang memiliki potensi untuk dikembangkan sebagai desa Agroindustri. Informan penelitian ditentukan dan dipilih secara sengaja sesuai dengan karakteristik penelitian, yaitu: (1) para pemimpin \& tokoh 
masyarakat setempat; (2) warga masyarakat; (3) pengusaha rumah tangga. Instrumen penelitian ini menggunakan focus group discussion (FGD) dan wawancara mendalam atau indepth interview.

\section{HASIL DAN PEMBAHASAN}

Penelitian ini akan menjawab beberapa permasalahan yaitu : bagaimana potensi pengembangan desa Gondangan sebagai klaster agroindustri ? bagaimanakah sikap masyarakat tentang pengembangan UMKM di desa Gondangan menjadi kawasan Agroindustri ? Bagaimana partisipasi masyarakat dalam pengembangan UMKM di desa Gondangan menjadi kawasan Agroindustri ? Berikut disampaikan hasil penelitian yang telah dilakukan.

\section{1) Pengembangan Klaster Agroindustri}

Agroindustri adalah merupakan sub sistem pencipta nilai tambah dari sebuah komoditas primer hasil pertanian. Melalui agroindustri ini maka sebuah komoditas pertanian diderivasi terus sampai sehilir-hilirnya untuk menghasilkan produk dengan nilai tambah yang lebih tinggi. Semakin banyak produk hilir yang tercipta dari komoditas tersebut maka semakin banyak nilai tambah yang dihasilkan sehingga pada akhirnya akan semakin besar memberikan kemanfaatan masyarakat secara keseluruhan. Semakin tinggi nilai yang tercipta dari turunan produk tersebut maka akan semakin tinggi pula nilai komoditas primer yang menjadi basis produk tersebut. (Kusnandar et.all,2012).

Secara umum ditinjau dari beberapa aspek yaitu aspek hukum, sosial ekonomi, aspek pemasaran, aspek teknik, dan teknologi, aspek manajemen dan aspek keuangan, Desa Gondangan Kecamatan Jogonalan berpotensi untuk dijadikan Desa Kawasan Agroindustri, walaupun masih banyak yang perlu diperbaiki dan dipersiapkan. Desa ini mempunyai potensi sebagai kawasan agroindustri makanan ringan. Mengingat banyak sekali pengusaha makanan ringan yang ada di Desa ini yaitu sebanyak 101 pengusaha yang tergabung dalam kelompok usaha makana ringan. Para pengusaha ini mampu menggerakkan perekonomian warga sehingga menjadikan desa Gondangan sebagai kawasan yang mempunyai kemandirian ekonomi cukup tinggi. Para pengusaha ini juga telah mempunyai pasar yang jelas dan mampu menopang produk yang dihasilkan anggota kelompok usaha. Kemungkinan lain Desa Gondangan bisa dijadikan desa penyangga kawasan Agrowisata bagi kawasan lain.

Pembentukan kluster ini dapat meningkatkan kapasitas pelaku usaha serta meningkatkan daya saing produk makanan ringan. Pendekatan klaster industri dalam pembangunan ekonomi daerah dapat menjadi alat yang efektif bagi kebijakan pembangunan ekonomi daerah dan kebijakan teknologi terpadu. Bagi pelaku ekonomi khususnya Usaha Mikro, Kecil, dan Menengah (UMKM), pendekatan klaster industri membantu upaya yang lebih fokus bagi terjalinnya kemitraan yang saling menguntungkan dan pengembangan jaringan bisnis yang luas. Sementara itu, bagi pembuat kebijakan, pendekatan ini memungkinkan skala pengaruh dari kebijakan dan program serta cakupan dampak yang signifikan. Selain itu pengembangan kluster agroindustri makanan ringan dapat dijadikan sebagai bentuk pengembangan wilayah di Jogonalan dengan memenuhi persyaratan berikut (1) kawasan ini harus memiliki spesialisasi; (2) terdapat industri pendorong berdaya saing; (3) mempunyai skenario keterkaitan antara sektor unggulan dengan sektor pendorong; (4) memfokuskan strategi pengembangan kepada produk berdaya saing dan berorientasi pada pasar regional; (5) memiliki sinergitas antar program; (6) perlunya peran pemerintah sebagai katalisator dan fasilitator. 


\section{2) Sikap masyarakat}

Sikap merupakan pernyataan evaluatif terhadap objek, orang atau peristiwa. Hal ini mencerminkan perasaan seseorang terhadap sesuatu. Sikap masyarakat tentang pengembangan UMKM dapat dideskripsikan sebagai berikut :

(1) Pelaku UMKM. Sikap pelaku UMKM terbagi menjadi dua kelompok. Kelompok pertama menyatakan setuju dengan pengembangan UMKM sedangkan kelompok lainnya kurang setuju. Hal i ni merujuk pada hasil wawancara dengan beberapa pelaku UMKM dimana sebagian besar menjawab sudah puas dengan keadaan sekarang, "ngeten niki pun payu kok" (seperti ini saja sudah laku). Artinya mereka sudah merasa cukup dan tidak perlu memikirkan tentang pengembangan atau merubah apa yang biasa mereka lakukan. Budaya "narimo" atau sikap sudah merasa cukup dan puas dengan apa yang telah diraih ternyata sangat kental di Desa Gondangan. Sikap ini berdampak pada kurangnya minat UMKM ketika diadakan pelatihan-pelatihan, kurang minat untuk melakukan pameran-pameran produk, meskipun kadang sudah difasilitasi.

(2) Pemerintah setempat. Secara umum pemerintah setempat dalam hal ini adalah pemerintah desa, mendukung upaya atau program pengembangan UMKM. Hal ini ditunjukkan dengan kesiapsediaan dalam memfasilitasi segala kegiatan yang berkaitan dengan pengembangan UMKM di wilayahnya. Pemerintah desa selalu terbuka dalam hal kegiatan-kegiatan yang berhubungan UMKM, selalu bersedia menerima kerjasama dari fihak manapun dalam upaya pengembangan UMKM misalnya kegiatan-kegiatan perguruan tinggi baik yang dilaksanakan oleh dosen maupun mahasiswa.

(3) Masyarakat umum. Sikap dari masyarakat umum relatif beragam. Bagi golongan masyarakat yang tidak mempunyai kepentingan terhadap UMKM cenderung tidak peduli dan masa bodoh karena mereka merasa tidak mendapat keuntungan ataupun kerugian dengan adanya program pengembangan UMKM. Mereka berpendapat bahwa rejeki sudah ada yang mengatur, semua sudah punya rejeki masing-masing, sehingga jika UMKM perlu dikembangkan silakan saja yang penting tidak saling mengganggu. Namun secara umum mereka tidak keberatan atau mendukung pengembangan UMKM di daerahnya.

\section{3) Partisipasi Masyarakat}

Partisipasi masyarakat adalah ikut sertanya seluruh anggota masyarakat dalam memecahkan permasalahan-permasalahan dalam masyarakat tersebut. Partisipasi adalah keterlibatan sukarela oleh masyarakat dalam perubahan yang ditentukan sendiri. Berkaitan dengan partisipasi masyarakat, berikut gambaran hasil penelitian.

(1) Pelaku UMKM. Sebagian pelaku UMKM sangat antusias ingin berkembang hal ini ditunjukkan dengan partisipasi dan kemauan mengikuti kegiatan-kegiatan yang dilakukan pemerintah atau pihak lain berkaitan dengan pengembangan UMKM. Sementara itu sebagian UMKM yang lain, partisipasinya biasa-biasa saja, seperti dijelaskan di depan sebagian dari pelaku UMKM sudah merasa nyaman dengan kondisinya saat ini dan, sikap atau budaya "narimo", merasa sudah cukup, usahanya sudah menghasilkan keuntungan, sudah laku, dan sebagainya masih banyak muncul di kalangan UMKM. Sehingga mereka enggan untuk aktif berpartisipasi karena merasa tidak perlu bahkan justru menghabiskan waktu mereka. 
(2) Pemerintah. Partisipasi pemerintah, dalam hal ini pemerintah desa, untuk pengembangan UMKM sangatlah mendukung. Hasil interview dengan pemerintah desa dapat disimpulkan bahwa pemerintah sangat mendukung semua program pengembangan UMKM. Banyak fasilitas yang sudah dilakukan pemerintah dalam rangka pengembangan UMKM, misalnya pemerintah desa juga memfasilitasi dan mengadakan pelatihan-pelatihan untuk meningkatkan kemampuan dan ketrampilan UMKM. Pemerintah desa juga sering mendorong, mengikutsertakan serta memfasilitasi UMKM dalam kegiatan pameran-pameran produk dan lain sebagainya. Pemerintah sering mengadakan forum-forum kerja sama dengan fihak luar untuk menampung partisipasi masyarakat dan untuk mengekpresikan partisipasinya dalam hal hal pengembangan UKM. Forum-forum tersebut digunakan sebagai akses masyarakat dalam menyampaikan pendapat mengenai pengembangan UKM.

\section{KESIMPULAN DAN SARAN}

\section{Kesimpulan}

1. Desa Gondangan mempunyai potensi untuk dikembangkan sebagai kawasan klaster agroindustri karena telah memenuhi persyaratan baik ditinjau dari aspek teknologi, hukum, ekonomi, maupun pemasaran.

2. Sikap masyarakat, pelaku usaha, sertra pemerintah terhadap pengembangan desa gondangan sebagai kawasan agroindustri sangat mendukuing.

3. Partisipasi masyarakat dalam kaitan pengembangan desa Gondangan sebagai klaster agroindustri beragam. Pemerintah berpartisipasi aktif dalam mewujudkan kawasan agroindustri. Sementara bagi pelaku usaha partisipasinya rendah. Mereka menganggap bahwa rencana tersebut kurang menarik karena mereka telah merasa cukup dengfan kondisi yang ada.

4. Partisipasi masyarakat cenderung pasif karena mereka merasa tidak bersangkutan langsung dan tidak diuntuingkan maupun dirugikan.

\section{Saran}

1. Potensi pengembangan klaster agroindustri tersebut perlu segera direalisasikan dengan membenahi kekurangan yang masih ditemukan.

2. Untuk meningkatkan partisipasi masyarakat perlu disusun skedul pelaksanaan kerja serta peta kekuatan yang dimiliki desa Gondangan agar para pelaku usaha tertarik untuk berpartisipasi secara aktif. Karena dari hasil penelitian ditemukan bahwaalasan enggan berpartisipasi karena mereka belum menyadari nilai tambah yang akan diperoleh jika kawasan tersebut menjadi klaster agroindustri. 


\section{DAFTAR PUSTAKA}

Badri, Sutrisno, 2012, Keunggulan Kompetetif pada Sistem Agroindustri Kelapa Sawit dengan Penerapan Model Klaster Agroindustri, journal.unwidha.ac.id

Indarwanta, Didik, Eny Endah Pujiastuti, Suratna, , 2010, Kajian Potensi (Study Kelayakan) Pengembangan Agroindustri di Desa Gondangan Kecamatan Jogonalan Klaten.penelitian dengan dana LPPM UPN "Veteran" Yogyakarta

Indarwanta, Didik,Eny Endah Pujiastuti, Suratna, , 2012, Pengaruh Kelompok Rujukan terhadap motivasi pengusaha UMKM untuk mengembangkan usaha, penelitian dengan dana Program Studi UPN "Veteran" Yogyakarta

Disperindag, 2004 Strategi Industri Nasional, Departemen Perindustrian dan Perdagangan, Jakarta

Saaty, Thomas L., 1992, "Decision Making for Leaders The Analitycal Hirarchy Proses for Decisions". Pitsburgh

Marimin. 2005. Teori dan Aplikasi Sistem Pakar dalam Teknologi Manajerial. Bogor : IPB Press.

Pedoman Teknis Pengembangan Agroindustri Tanaman Pangan TA 2012, Direktorat Pengolahan Hasil Pertanian Direktorat Jenderal Pengolahan dan Pemasaran Hasil Pertanian

Porter, 2000. "M. Competitive Strategy : Techniques for Analyzing Industries and Competitors". With a New Introduction The Free Press.

Sugiarto, M Syamsul Ma'arif2, Illah Sailah, Sukardi, Suharto Honggoku, 2011,Pemilihan Strategi Pengembangan Klaster Industri dan Strategi Manajemen pada Klaster Industri Barang Celup lateks, J. Tek. Ind. Pert. Vol. 20 (2), 89-100, Journal.ipb.ac.id 